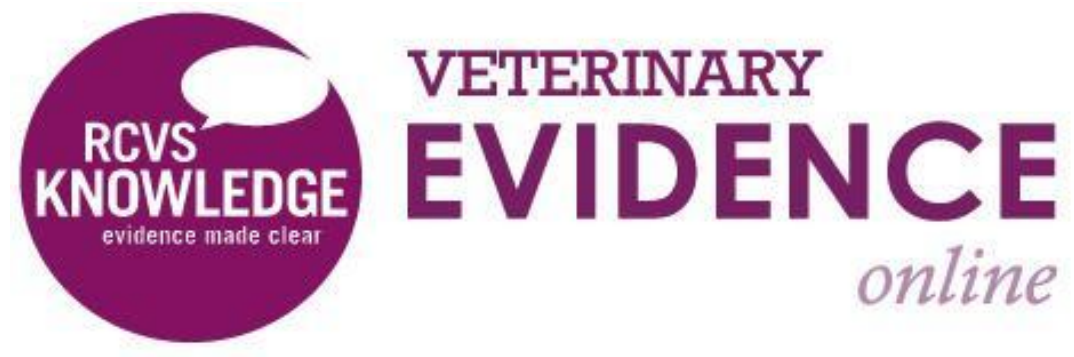

\title{
Does Adding Transdermal Nitroglycerine to Other Therapies Used for Management of Left-sided Congestive Heart Failure in Dogs Speed the Resolution of Clinical Signs?
}

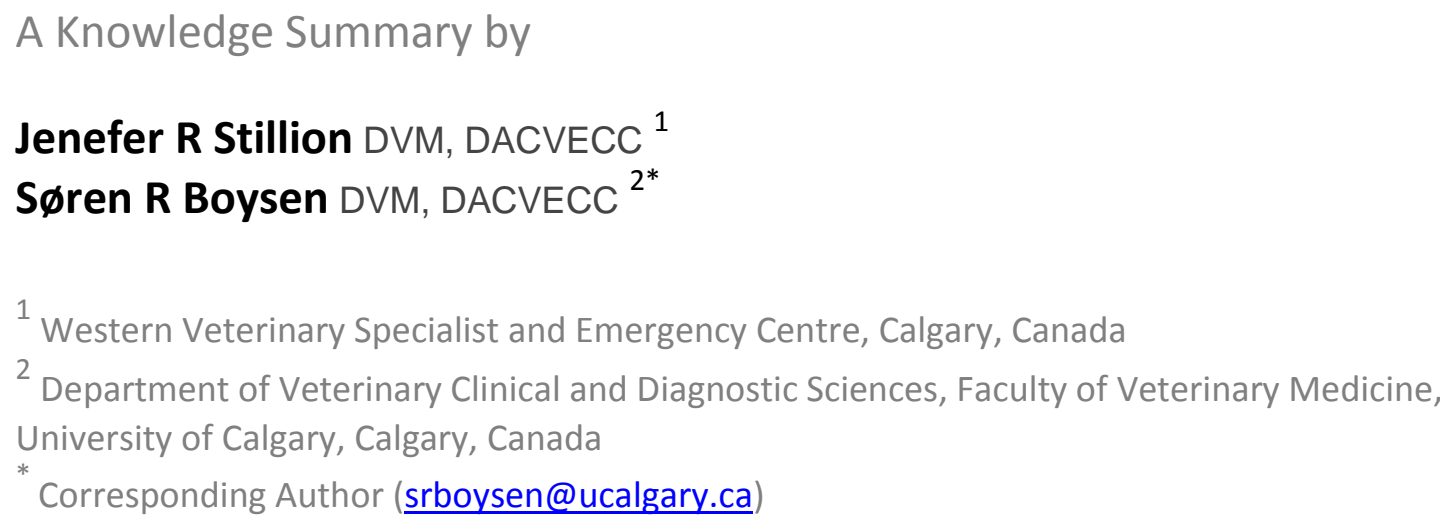

There is an erratum to this paper published in Veterinary Evidence Vol 3, Issue 1 (2018): http://dx.doi.org/10.18849/ve.v3i1.168

ISSN: 2396-9776

Published: 12 Dec 2017

Updated: 01 Feb 2018

In: Vol 2, Issue 4

DOI: http://dx.doi.org/10.18849/ve.v2i4.115

Reviewed by: Myra Forster-van Hijfte (CertVR CertSAM DipECVIM-CA FRCVS) and William Chandler (BVetMed, MRCVS) 


\section{KNOWLEDGE SUMMARY}

\section{Clinical bottom line}

There is very weak veterinary clinical and experimental evidence based upon a limited number of studies to indicate that adding transdermal nitroglycerine to other therapies used for management of left-sided congestive heart failure in dogs speeds the resolution of clinical signs.

\section{Question}

Does adding transdermal nitroglycerine to other therapies used for management of left-sided congestive heart failure in dogs speed the resolution of clinical signs?

\section{Clinical Scenario}

Transdermal nitroglycerin is frequently recommended as an adjunct therapy in many canine treatment protocols for left-sided congestive heart failure due to its preload and afterload reducing effects. Does adding transdermal nitroglycerin to other therapies used for management of left-sided congestive heart failure in dogs speed the resolution of clinical signs?

\section{The Evidence}

There is no evidence in the literature to suggest transdermal nitroglycerin speeds resolution of clinical signs in dogs with pulmonary oedema secondary to left-sided congestive heart failure. There is equivocal to weak evidence that transdermal nitroglycerin reduces systolic and/or mean arterial blood pressure in dogs. There is no evidence that transdermal nitroglycerin has any effect on resolution of any clinical signs of left-sided congestive heart failure. Although there are no reports of adverse harm associated with transdermal nitroglycerin, there are insufficient clinical studies to be able to state nitroglycerin does not have any adverse affects in dogs.

\section{Summary of the evidence}

\begin{tabular}{|r|l|}
\hline \multicolumn{2}{|l|}{ Nakayama (2007) } \\
\hline Sopulation: & mixed breed dogs with Seller's grades 2+ or 3+ mitral regurgitation \\
\hline Sample size: & 9 dogs \\
\hline Intervention details: & $\begin{array}{l}\text { Mitral regurgitation was produced by surgical disruption of the } \\
\text { mitral valves. Five months after production of mitral regurgitation, } \\
\text { left atrial dimension and ventricular function were measured using } \\
\text { echocardiography/Doppler and left ventricular micromanometry. } \\
\text { Nine mixed breed dogs weighing 21-32 kg were administered } \\
\text { butorphanol (0.05 mg/kg IM) prior to the start of each study. } \\
\text { Enalaprilat, nitroglycerin, ouabain, milrinone or placebo (IV saline, } \\
\text { There was a one-week washout period between arms of the study to } \\
\text { ensure at least } 10 \text { half-lives between exposures. Recordings were } \\
\text { obtained, along with an ECG, during baseline and 30 minutes after }\end{array}$ \\
\hline
\end{tabular}




\begin{tabular}{|r|l|}
\hline & $\begin{array}{l}\text { dogs received IV (in random sequence) } 0.3 \mathrm{mg} / \mathrm{kg} \text { enalaprilat, } \\
20 \mathrm{mg} / \mathrm{kg} \text { ouabain, or 100mg/kg of milrinonel; or 2 inches of 2\% } \\
\text { nitroglycerin paste applied to the skin of the inner thigh over an area } \\
\text { of } 16 \mathrm{~cm}^{2} \text {. All dogs also were given an IV (saline) and a transdermal } \\
\text { placebo (Vaseline). Dogs were studied 1 hour and } 2 \text { hours after } \\
\text { application. }\end{array}$ \\
\hline Study design: & Randomised controlled clinical trial \\
\hline Outcome studied: & $\begin{array}{l}\text { The effect of 4 different cardioactive drugs on left ventricular } \\
\text { function in dogs with mitral regurgitation of } 5 \text { months duration. } \\
\text { Parameters studied included intracardiac dimension, peak aortic } \\
\text { flow, left atrial diastolic and systolic function. }\end{array}$ \\
\hline Main findings: & $\begin{array}{l}\text { When compared to placebo (Vaseline), transdermal } \\
\text { nitroglycerin failed to produce an effect on any of the } \\
\text { parameters studied. }\end{array}$ \\
\hline Limitations: & $\begin{array}{l}\text { Small sample size. Surgically induced mitral regurgitation may not } \\
\text { accurately reflect clinical mitral endocardiosis. No animals had } \\
\text { clinical signs of congestive heart failure. }\end{array}$ \\
\hline
\end{tabular}

\begin{tabular}{|c|c|}
\hline Kanda (1995) & \\
\hline Population: & Healthy Beagle dogs \\
\hline Sample size: & 5 dogs in each group \\
\hline Intervention details: & $\begin{array}{l}\text { There were } 3 \text { groups; Nitroglycerin tape at } 2.5 \mathrm{mg} / \mathrm{kg} \text { (NT-I, } 5 \mathrm{mg} \\
\text { nitroglycerin per } 5 \times 10 \mathrm{~cm} 2 \text { ) with placebo capsule, nifedipine given } \\
\text { orally ( } 3 \mathrm{mg} / \mathrm{kg} \text { ) with placebo tape, and a control group that received } \\
\text { a placebo (blank) capsule orally and pacebo tape. Placebo and } \\
\text { nitroglycerine tape were applied to a clipped area of skin on the } \\
\text { chest of healthy beagle dogs. }\end{array}$ \\
\hline Study design: & Prospective study (non-randomised, non-blinded) \\
\hline Outcome studied: & $\begin{array}{l}\text { The effect of nitroglycerin tape compared to placebo tape on blood } \\
\text { pressure (systolic and diastolic), heart rate and coronary blood flow } \\
\text { in healthy beagle dogs. Baseline values recorded for } 1 \text { hour before } \\
\text { drug administration and then at } 30 \text { min, } 1 \text { hour and every hour until } \\
9 \text { hours. Parameters were measured again } 1 \text { hours following } \\
\text { removal of tape. }\end{array}$ \\
\hline $\begin{array}{l}\text { Main findings: } \\
\text { (relevant to PICO question): }\end{array}$ & $\begin{array}{l}\text { Systolic blood pressure was decreased by } 10-15 \% \text {, } \\
\text { compared to baseline, with application of nitroglycerin tape } \\
\text { in awake healthy instrumented beagle dogs. The decrease } \\
\text { was noted } 1 \text { hour after application, persisted for the } \\
\text { duration of the study and returned to baseline values within } \\
1 \text { hour of removing the tape. } \\
\text { - Calculated (not directly measured) mean arterial pressure } \\
\text { decreased } 4-5 \% \text {. } \\
\text { - Diastolic blood pressure and heart rate were not affected. }\end{array}$ \\
\hline
\end{tabular}




\begin{tabular}{|c|c|}
\hline & $\begin{array}{l}\text { Changes were noted } 30 \text { minutes after the application of } \\
\text { nitroglycerin tape and remained constant for 8h. } \\
\text { No changes from baseline parameters were noted in the } \\
\text { control group. }\end{array}$ \\
\hline Limitations: & $\begin{array}{l}\text { Small sample size may have failed to detect true differences that } \\
\text { existed between groups or within groups. Decrease in blood } \\
\text { pressure provides indirect evidence of the efficacy of nitroglycerin } \\
\text { which does not equate to clinical improvement. Dogs were healthy } \\
\text { and did not have any clinical signs of congestive heart failure. }\end{array}$ \\
\hline
\end{tabular}

\begin{tabular}{|c|c|}
\hline \multicolumn{2}{|l|}{ McKie (2014) } \\
\hline Population: & Male mongrel dogs with induced mild left ventricular dysfunction. \\
\hline Sample size: & $\begin{array}{l}\text { Three study groups with } 7 \text { dogs in each group (intravenous M-ANP, } \\
\text { nitroglycerin, and vehicle } 0.9 \% \text { normal saline) }\end{array}$ \\
\hline Intervention details: & $\begin{array}{l}\text { Mild left ventricular dysfunction was induced via right ventricular } \\
\text { pacing at } 180 \text { beats per minute for } 10 \text { days in male mixed mongrel } \\
\text { dogs. RV pacing was terminated the day of the study and dogs were } \\
\text { anesthetized with pentobarbital sodium ( } 15 \mathrm{mg} / \mathrm{kg} \mathrm{IV}) \text {, intubated and } \\
\text { ventilated. Hypertension was induced in instrumented dogs via IV } \\
\text { administration of Angiotensin II ( } 40 \mathrm{mg} / \mathrm{kg} / 1 \mathrm{~min} \text { ). Dogs were then } \\
\text { administered either M-ANP ( } 30 \mathrm{pmol} / \mathrm{kg} / \mathrm{min}) \text {, nitroglycerin ( } 10 \\
\text { ug/kg IV) or } 0.9 \% \text { normal saline at a rate of } 1 \mathrm{ml} / \mathrm{min} \text {. }\end{array}$ \\
\hline Study design: & $\begin{array}{l}\text { Prospective experimental study under anaesthesia (non- } \\
\text { randomised, non-blinded) }\end{array}$ \\
\hline Outcome studied: & $\begin{array}{l}\text { Blood pressure, PCWP, systemic vascular resistance, left ventricular } \\
\text { filling pressures, heart rate, cardiac output. }\end{array}$ \\
\hline $\begin{array}{l}\text { Main findings: } \\
\text { (relevant to PICO question): }\end{array}$ & $\begin{array}{l}\text { - Nitroglycerin significantly decreased mean arterial blood } \\
\text { pressure, PCWP, systemic vascular resistance and left } \\
\text { ventricular filling pressures. } \\
\text { - No effect on heart rate or cardiac output. }\end{array}$ \\
\hline Limitations: & $\begin{array}{l}\text { Nitroglycerin was administered IV, not topically. Sample size was } \\
\text { small. Study was not blinded or randomised. Experimentally induced } \\
\text { heart failure was studied, not naturally occurring heart failure. } \\
\text { Evidence provided that IV nitroglycerin reduced preload and } \\
\text { afterload but this does not equate to improvement in clinical signs. }\end{array}$ \\
\hline
\end{tabular}

\begin{tabular}{|r|l|}
\hline \multicolumn{2}{|l|}{ Parameswaran (1999) } \\
\hline Population: & Healthy anaesthetised dogs \\
\hline Sample size: & 15 dogs \\
\hline Intervention details: & $\begin{array}{l}\text { Sonomicrometer crystals were applied to the spleen in each dog and } \\
\text { a pressure-measuring catheter was inserted into a splenic vein. A }\end{array}$ \\
\hline
\end{tabular}




\begin{tabular}{|c|c|}
\hline & $\begin{array}{l}2.5 \mathrm{~cm} \text { strip of transdermal } 2 \% \text { nitroglycerin ointment was applied to } \\
\text { the inner surface of the pinna in } 10 \text { dogs and } 5 \text { additional dogs } \\
\text { (control group) were given only petrolatum. }\end{array}$ \\
\hline Study design: & Non-randomised clinical trial \\
\hline Outcome studied: & $\begin{array}{l}\text { Splenic dilatation in healthy dogs anaesthetised with alpha } \\
\text { chloralose after transdermal application of nitroglycerin. Splenic } \\
\text { dimension and venous pressure were measured for } 10 \text { minutes } \\
\text { before application and time from application of transdermal } \\
\text { nitroglycerin to the initial change in dimension and to the maximal } \\
\text { change in dimension (measured to the nearest second). }\end{array}$ \\
\hline $\begin{array}{l}\text { Main findings: } \\
\text { (relevant to PICO question): }\end{array}$ & $\begin{array}{l}\text { - Splenic dimension increased significantly from baseline in all } \\
10 \text { dogs receiving transdermal nitroglycerin. } \\
\text { - Splenic enlargement was noted within } 482 \pm 652 \text { seconds } \\
\text { after application of transdermal nitroglycerin with maximal } \\
\text { dilatation at } 861 \pm 632 \text { seconds. } \\
\text { - Splenic venous pressure did not change significantly in dogs } \\
\text { receiving transdermal nitroglycerin or in control dogs. }\end{array}$ \\
\hline Limitations: & $\begin{array}{l}\text { Animals were healthy and anaesthetised with alpha chloralose, } \\
\text { whose physiologic effects are not well characterized in the literature } \\
\text { for any species. Results of the present study may not translate to un- } \\
\text { anaesthetised dogs with left-sided congestive heart failure. }\end{array}$ \\
\hline
\end{tabular}

\section{Appraisal, application and reflection}

Given studies are lacking with regards to the efficacy of transdermal nitroglycerin when included as an adjunct treatment to other therapies in dogs with left-sided congestive heart failure, it's use cannot be recommended in the management of these cases at this time. Future clinical studies are needed to evaluate the safety, efficacy and ideal dosage of transdermal nitroglycerin in the treatment of dogs with left-sided congestive heart failure.

\section{Methodology Section}

\begin{tabular}{|c|c|c|}
\hline \multicolumn{3}{|l|}{ Search Strategy } \\
\hline $\begin{array}{r}\text { Databases searched and dates } \\
\text { covered: }\end{array}$ & $\begin{array}{l}\text { Pubm } \\
\text { Week }\end{array}$ & $\begin{array}{l}\text { Platform 1973- Week } 1 \text { 2017], CAB Abstracts <1973 to } 2016 \\
\text { 1> }\end{array}$ \\
\hline Search terms: & $\begin{array}{l}3 \\
4\end{array}$ & $\begin{array}{l}\text { med } \\
\text { Search ((((glyceryl trinitrat*) OR glyceryltrinitrat*) OR } \\
\text { trinitrat glycerin*) OR nitro glycerin*) OR nitroglycerin* } \\
\quad 16518 \\
\text { Search (((((((heart) OR cardiac) OR CHF) OR cardio*) OR left } \\
\text { ventricular) OR left ventricle*) OR LV) OR heart diseases) OR } \\
\text { cardiovascular diseases } 2866548 \\
\text { Search (((((dog) OR dogs) OR canine) OR bitch*) OR canis) } \\
\text { OR bitches 351249 } \\
\text { Search ((transdermal) OR cutaneous) OR ointment }\end{array}$ \\
\hline
\end{tabular}


CAB Abstracts:

1. ("glyceryl trinitrat*" or glyceryltrinitrat* or "trinitro glycerin*" or trinitroglycerin* or "nitro glycerin*" or nitroglycerin*).mp. [mp=abstract, title, original title, broad terms, heading words, identifiers, cabicodes] (374)

2. (heart or cardiac or CHF or cardio* or "left ventricular" or "left ventricle*" or "left ventrical*" or "LV").mp. or heart diseases/ or cardiovascular diseases/ [mp=abstract, title, original title, broad terms, heading words, identifiers, cabicodes] (151135)

3. (dog or dogs or canine or bitch*).mp. or dogs/ or canis/ or bitches/ (192085)

4. 1 and 2 and 3 (16)

Dates searches performed: 22/12/2016 (CAB) 02/01/2017 (Pubmed)

\section{Exclusion / Inclusion Criteria}

Exclusion: Study design did not involve dogs and/or was not relevant to the research questions asked

Inclusion: Any relevant primary veterinary research or systematic review which compared transdermal nitroglycerine to other therapies to answer the following question; "Does adding transdermal nitroglycerine to other therapies used for management of left-sided congestive heart failure in dogs speed the resolution of clinical signs?"

\section{Search Outcome}

\begin{tabular}{|l|c|c|c|c|c|c|c|}
\hline Database & $\begin{array}{c}\text { Number } \\
\text { of } \\
\text { results }\end{array}$ & $\begin{array}{c}\text { Excluded } \\
\text { Did not } \\
\text { address } \\
\text { the PICO }\end{array}$ & $\begin{array}{c}\text { Excluded }- \\
\text { Proceedings } \\
\text { and review } \\
\text { articles with no } \\
\text { evidence }\end{array}$ & $\begin{array}{c}\text { Excluded - } \\
\text { Given IV, did } \\
\text { not compare } \\
\text { groups, and } \\
\text { did not } \\
\text { address } \\
\text { clinical } \\
\text { question }\end{array}$ & $\begin{array}{c}\text { Excluded - } \\
\text { Single case } \\
\text { report with } \\
\text { no evidence } \\
\text { to the } \\
\text { question }\end{array}$ & $\begin{array}{c}\text { Duplicate } \\
\text { results }\end{array}$ & $\begin{array}{c}\text { Total } \\
\text { relevant } \\
\text { papers }\end{array}$ \\
\hline PubMed & 10 & 6 & 0 & 0 & 0 & 0 & 4 \\
\hline $\begin{array}{l}\text { CAB } \\
\text { Abstracts }\end{array}$ & 16 & 0 & 6 & 6 & 2 & 2 & 0 \\
\hline Total relevant papers when duplicates removed & & & & & \\
\hline
\end{tabular}




\section{CONFLICT OF INTEREST}

The author declares no conflict of interest.

\section{REFERENCES}

1. Kanda A, Yoshida M, Kanou M, et al. (1995). Cardiovascular effects of NT-1, a new patch form of nitroglycerin, alone and in combination with nifedipine in conscious dogs. Journal of Pharmacy Pharmacology. 47(12A): pp. 1021-1024. DOI: http://dx.doi.org/10.1111/j.2042-7158.1995.tb03289.x

2. McKie PM, Cataliotti A, Ichiki T, et al. (2014). M-atrial natriuretic peptide and nitroglycerin in a canine model of experimental acute hypertensive heart failure: differential actions of 2 cGMP activating therapeutics. Journal of the American Heart Association, 3(1):e000206.

DOI: http://dx.doi.org/10.1161/JAHA.113.000206

3. Nakayama, T. Nishijima, Y. Miyamoto, et al. (2007). Effects of 4 classes of cardiovascular drugs on ventricular function in dogs with mitral regurgitation. Journal of Veterinary Internal Medicine, 21(3), pp. 445-450. PMID: 17552449 DOI: http://dx.doi.org/10.1111/j.1939-1676.2007.tb02988.x

4. Parameswaran, N. Hamlin, R. L. Nakayama, T. Rao, S. S. (1999). Increased splenic capacity in response to transdermal application of nitroglycerin in the dog. Journal of Veterinary Internal Medicine, 13(1), pp. 44-46. PMID: 10052063 DOI: 1111/j.1939-1676.1999.tb02164.x

5. Sellers R, Levy M, Amplatz K, Lillehei CW. Left retrograde cardioangiography in acquired cardiac disease: Technic, indications and interpretations in 700 Am J Cardiol 1964;14: 437-447 DOI: http://dx.doi.org/10.1016/0002-9149(64)90027-X 


\section{Cinam \\ ochese}

\section{Intellectual Property Rights}

Authors of Knowledge Summaries submitted to RCVS Knowledge for publication will retain copyright in their work, and will be required to grant to RCVS Knowledge a non-exclusive license of the rights of copyright in the materials including but not limited to the right to publish, re-publish, transmit, sell, distribute and otherwise use the materials in all languages and all media throughout the world, and to license or permit others to do so.

\section{Disclaimer}

Knowledge Summaries are a peer-reviewed article type which aims to answer a clinical question based on the best available current evidence. It does not override the responsibility

of the practitioner. Informed decisions should be made by considering such factors as individual clinical expertise and judgement along with patient's circumstances and owners' values. Knowledge Summaries are a resource to help inform and any opinions expressed within the Knowledge Summaries are the author's own and do not necessarily reflect the view of the RCVS Knowledge.

Veterinary Evidence and EBVM Network are RCVS Knowledge initiatives. For more information please contact us at editor@veterinaryevidence.org

RCVS Knowledge is the independent charity associated with the Royal College of Veterinary Surgeons (RCVS). Our ambition is to become a global intermediary for evidence based veterinary knowledge by providing access to information

that is of immediate value to practicing veterinary professionals and directly contributes to evidence based clinical decision-making.

www.veterinaryevidence.org

RCVS Knowledge is a registered Charity No. 230886. Registered as a Company limited by guarantee in England and Wales No. 598443.

Registered Office:

Belgravia House

62-64 Horseferry Road

London SW1P 2AF 